\title{
ІНСТРУМЕНТИ ЗАКОНОДАВЧОГО РЕГУЛЮВАННЯ СКИДАННЯ ЗАБРУДНЮЮЧИХ РЕЧОВИН В ЄВРОПЕЙСЬКОМУ СОЮЗІ ТА В УКРАЇНI
}

\author{
Уберман В. І., Васьковець Л. А.
}

\section{ВСТУП}

Запровадження в Україні європейської системи забезпечення доброї якості води в її природних джерелах вимагає створення відповідних еколого-правових підстав та ефективних законодавчих інструментів. В екологічному законодавстві $\mathrm{CC}$ належні вимоги зосереджено в еколого-правовому інституті якості вод та ії регулювання (ЕПІЯВР) і в інституті інтегрованого запобігання та контролю промислового забруднення, ключовим елементом якого є інтегрований дозвіл (ІД). Норми європейського ЕПІЯВР містяться в багатьох актах екологічної частини асquis ЄС. Імплементація законодавства ЄС належить до міжнародних зобов'язань України ${ }^{1}$. Важливою складовою частиною ЕПІЯВР є підінститут регулювання скидання забруднюючих речовин (РСЗР), до якого входять еколого-правові інструменти, що впливають на якість вод шляхом обмеження емісії (виділення) забруднюючих речовин (ЗР) зі зворотною водою і мають назву нормативів граничного значення викидів (ГЗВ). Системне вивчення зазначеного підінституту ініційовано авторами цієї статті в роботі². Протягом 2010-2019 років в Україні здійснювалися головні кроки реформування державного управління в галузі охорони та раціонального використання вод, його адаптації до європейського водного законодавства шляхом впровадження інтегрованого управління водними ресурсами за басейновим принципом (ІУВРБП). Правові

\footnotetext{
1 Рекомендації для українських органів державного управління щодо наближення до права ЄС. Київ, 2018. 104 p. URL: https://eu-ua.org/sites/default/files/inline/files/legal approximation_guidelines_ukr_new.pdf (дата звернення 09.02.2020).

2 Уберман В.І., Васьковець Л.А. Еколого-правові особливості імплементації Україною законодавства ЄС про регулювання скидання забруднюючих речовин. In book : International scientific and practical conference "New challenges of legal science in Ukraine and EU countries" Miskolc, Hungary, April 19-20, 2019. Miskolc: Izdevnieciba "Baltija Publishing", 2019. P. $437-440$.
} 
аспекти такого управління досліджувалися, зокрема, в роботах ${ }^{3,4,5}$. Центральною ланкою реформування $є$ перехід до європейського законодавчого регулювання скидання 3Р, без якого неможливо досягнути цілей забезпечення європейської якості вод. За ст. 42 Водного кодексу України (ВКУ) ${ }^{6}$, скидання ЗР є одним із видів спеціального водокористування, яке розглядається як складова частина ІУВРБП. 3 іншого боку, у водному законодавстві ЄС інститут спеціального водокористування відсутній. За ст. 10 Водної рамкової директиви ЄС (ВРД) ${ }^{7}$, еколого-правові інструменти регулювання якості вод шляхом впливу на емісії ЗР пов'язані 3 комбінованим підходом до регулювання, який вимагає або здійснення емісії ЗР на базі найкращих доступних методів (НДМ) або відповідних ГЗВ, або з дотриманням стандартів якості довкілля (СЯД). Нині НДМ або подібних йому інструментів у водному законодавстві України немає, а в галузі охорони вод, крім очищення міських стічних вод, відсутнє відповідне нормативно-методичне, організаційне та інженерно-екологічне забезпечення. Крім ВРД та інших директив водного сектору, зокрема, Директиви 2008/105/ЄС про стандарти якості довкілля в галузі водної політики $(\text { ДСЯД })^{8}$, на еколого-правові інструменти нормативного скидання ЗР поширюється також вимоги загальних екологічних директив $\mathrm{CC}$, насамперед, Директиви 2010/75/СС про промислові викиди (комплексне запобігання і контроль забруднень) (ДПВ).

Через існування різних перекладів ВРД та їх неузгодженість 3 українською науковою термінологією в подальших посиланнях

3 Данилюк Л.Р. Басейновий принцип управління водними ресурсами: поняття, зміст і стан впровадження в Україні. Науковий вісник Ужгородського наи.. ун-ту. Сер. Право. 2018. Вип. 51. Т. 1. С. 151-154. URL: http://www.visnyk-juris.uzhnu.uz.ua/file/No.51/part_1/34.pdf (дата звернення 09.02.2020).

4 Соколова А.К. Правові аспекти державного управління в галузі охорони вод і відтворення водних ресурсів. Проблеми законності. 2015. Вип. 128. С. 154-164. URL: http://nbuv.gov.ua/UJRN/Pz_2015_128_22 (дата звернення 09.02.2020).

5 Локтєва-Маклашова Н.В. Правові аспекти впровадження інтегрованих підходів в управління водними ресурсами за басейновим принципом. Науковий вісник Херсонського держ. ун-ту. Сер. Юридичні науки. 2017. Вип. 1(1). С. 142-144. URL: http://nbuv.gov.ua/ UJRN/Nvkhdu_jur_2017_1(1)_37 (дата звернення 09.02.2020).

6 Водний кодекс України. ВВР. 1995. № 24. Ст. 189. URL: https://zakon.rada.gov.ua/laws/ show/213/95-вр (дата звернення 09.02.2020).

7 Директива 2000/60/СС Європейського Парламенту і Ради «Про встановлення рамок діяльності Співтовариства в галузі водної політики» від 23 жовтня 2000 p. URL: https://zakon.rada.gov.ua/laws/show/994_962 (дата звернення 09.02.2020).

8 Директива 2008/105/ЄС Європейського Парламенту та Ради від 16 грудня 2008 р. про стандарти якості довкілля в галузі водної політики. URL: http://old.minjust.gov.ua/45875 (дата звернення 09.02.2020). 
перевага надається джерелу‥ Мета статті полягає у визначенні головних законодавчих інструментів європейського РСЗР із точкових джерел у поверхневі води для першочергової імплементації в українське водне законодавство та деяких еколого-правових проблем, що виникають при цьому.

\section{1. Законодавчі інструменти регулювання: поділ ЗР, СЯД, зони змішування}

На шляху імплементації ІД лише недавно розроблено проект ${ }^{10}$ концепції змін у дозвільній системі природокористування (законодавчі вимоги до якої досліджено в роботі $\left.{ }^{11}\right)$. До цього часу, як зазначено в роботі ${ }^{12}$, «українське законодавство встановлює фактично лише один вид природоресурсних дозволів, які надають право на здійснення одного виду природокористування стосовно одного природного ресурсу». Змінами у складі заходів із реформи дозвільної системи запроваджуються ІД для промисловості та галузеві керівництва 3 переліком НДМ. Через фактичний стан українських природоресурсних дозволів у цій статті перевага надається дослідженню нормативних, а не технологічних інструментів, які стосуються води. Нині єдиним реальним шляхом скорішого просування в бік дотримання європейських вимог під час скидання більшості ЗР варто вважати нормативне регулювання з орієнтацією на дотримання СЯД.

Першочерговим завданням (та етапом) апроксимації до вимог ВРД варто вважати встановлення законодавчого поділу (структури) всієї сукупності ЗР. У преамбулі до ВРД декларується її призначення для сприяння поступовому зменшенню скидів небезпечних речовин у воду (пар. 22), а кінцевою метою ВРД визначено усунення пріоритетних небезпечних речовин (пар. 27). Тобто вже на цільовому

\footnotetext{
9 Водний кодекс України.

10 Концепція реалізації державної політики у сфері промислового забруднення (проект розпорядження Кабінету Міністрів України. URL: https://menr.gov.ua/projects/140/ (дата звернення 09.02.2020).

11 Кобецька Н.Р. Інтегрований екологічний дозвіл: вимоги законодавства Європейського Союзу, практика реалізації в Польщі, перспективи для України. Науковий вісник Ужгородського наи. ун-ту. Сер. Право. 2018. № 51(1). C. 155-163. URL: http://www.visnyk-juris.uzhnu. uz.ua/file/No.51/part_1/35.pdf (дата звернення 09.02.2020).

12 Кобецька Н.Р. Система документів дозвільного характеру у сфері використання природних ресурсів. Актуальні проблеми вдосконалення чинного законодавства Украӥни. 2013. Вип. 33. С. 187-199. URL: http://nbuv.gov.ua/UJRN/apvchzu_2013_33_23 (дата звернення 09.02.2020).
} 
для охорони вод рівні (а також у ст. 16 ВРД) відбувається поділ всієї множини ЗР за ризиком для довкілля на небезпечні речовини, пріоритетні небезпечні речовини та решту речовин. Такий поділ послідовно реалізується в тексті ВРД та у додатках до нього. На відміну від ВРД, у тексті ВКУ поділ ЗР та згадка про їх властивості здійснені лише в дуже обмеженому обсязі стосовно: біогенних, радіоактивних, токсичних та нафтових ЗР. Ще й саме поняття ЗР у ст. 1 ВКУ «речовина, яка привноситься [виділено авторами] у водний об'єкт у результаті господарської діяльності людини» є релятивним і принципово відрізняється від визначення у ст. 2(31) ВРД: «<..> будь-яка речовина, що може спричинити забруднення, <..>», де за ст. 2(33) «забруднення» - означає пряме або непряме внесення в результаті діяльності людини речовин або тепла в повітря, воду або землю, що може бути небезпечним для здоров'я людини або якості водних екосистем чи для безпосередньо залежних від них наземних екосистем, що призводить до псування матеріальних цінностей, або до погіршення чи ушкодження корисних властивостей довкілля та можливості законного користування довкіллям». Отже, поняття ЗР у ВРД $\epsilon$ істотно більш широким за змістом, деталізованим та екологічним, спрямоване на запобігання можливим негативним реакціям та наслідкам. У ВКУ не передбачено поділу всіх $3 \boldsymbol{P}$ залежно від джерел їх надходження, хімічної природи, властивостей, впливу на людину та об'єкти довкілля (ризику шкоди), форм існування та поведінки у водному середовищі. В українських підзаконних актах використовується диференціація 3 Р за іниими принципами: залежно від категорії вод; для усіх випадків скидання та додаткових 3Р; за суб'єктами державного моніторингу вод. Навіть у найбільш релевантному Переліку ${ }^{13}$, крім назви показників або речовин та CAS\# (реєстраційний номер за Chemical Abstracts Service), не міститься жодних відомостей про небезпеку ЗР та пріоритетність ставлення до них. Принциповою особливістю ВКУ є те, що кодекс головним чином спрямовано не на ЗР як безпосередні чинники небезпеки та фактори ризику, а на їх носій-зворотну воду та її категорії, що видно з глави 14 ВКУ. Через таку невідповідність українська діяльність $з$ охорони якості вод залишається без законодавчо визначених

\footnotetext{
13 Перелік забруднюючих речовин для визначення хімічного стану масивів поверхневих і підземних вод та екологічного потенціалу штучного або істотно зміненого масиву поверхневих вод (затв. наказом Міністерства екології та природних ресурсів України 06.02.2017 p. № 45, зареєстр. в Міністерстві юстиції України 20 лютого 2017 р. за № 235/30103). URL: https://zakon.rada.gov.ua/laws/show/z0235-17?lang=ru (дата звернення 09.02.2020).
} 
цілей, послідовності їх досягнення, можливості зосередження зусиль та ресурсів. Для усунення зазначеної проблеми варто внести відповідні зміни у ВКУ та підзаконні акти, особливо у два акти $3^{14}$, щодо поділу ЗР за їхнім цільовим значенням для охорони вод.

До другого етапу апроксимації належить визначення поняття СЯД та його використання в українському законодавстві. СЯД за ст. 2(35) ВРД є критеріями захисту здоров'я людини та довкілля: концентрації окремої речовини-забрудника або групи речовин у воді, осаді або біоті, яка не має бути перевищена. Відповідно до часового періоду, який характеризується концентраціями ЗР, європейські СЯД визначаються двома показниками масової концентрації з одиницею виміру [мкг/дм $\left.{ }^{3}\right]$ : 1) СРП-СЯД - середній річний показник, 2) МДК-СЯД максимальна щорічно допустима концентрація.

В українському законодавстві відповідник СЯД відсутній, а широко застосовуваними у водокористуванні для подібних цілей та, на перший погляд, найбільш близькими до СЯД є гранично допустима концентрація (ГДК) речовини у воді, тобто за ст. 36 ВКУ нормативи екологічної безпеки водокористування для задоволення: 1) питних, господарсько-побутових та інших потреб населення (ГДКг/п); 2) потреб рибного господарства (ГДКр) ${ }^{15}$. Але нормативи ГДК принципово відрізняються від СЯД за об'єктами нормування (захисту): ГДК призначена для забезпечення водокористування у відповідних місцях водних об'єктів або в охоронних зонах за ст. 6 ВРД, і має одне (фіксоване) значення з одиницею виміру [мг/дм³]. Приклади відмінності європейських СЯД та ГДК наведено в табл. 1.

\footnotetext{
14 Про затвердження Порядку розроблення нормативів гранично допустимого скидання забруднюючих речовин у водні об'єкти та перелік забруднюючих речовин, скидання яких у водні об'єкти нормується (затв. постановою Кабінету Міністрів України від 11 вересня 1996 p. № 1100 (в редакції Постанови КМ № 1091 (1091-2017-п) від 13.12.2017 p. URL: http:// zakon.rada.gov.ua/laws/show/1100-96-п (дата звернення 09.02.2020).

15 Сближение с экологическим законодательством Европейского Союза в странах Восточной Европы, Кавказского региона и Средней Азии: Путеводитель. Люксембург. Бюро офиц. публ. Европейских Сообществ. 2003. 124 с. URL: https://ec.europa.eu/environment/ archives/enlarg/pdf/convergence_guide_ru.pdf (дата звернення 09.02.2020).
} 
Таблиця 1

\section{Стандарти якості довкілля (СЯД) для визначення хімічного стану внутрішніх поверхневих вод (за ч. А Додатку 1 до ДСЯД) та ГДК деяких 3Р}

\begin{tabular}{|c|c|c|c|c|}
\hline Назва речовини & $\begin{array}{c}\text { СРП- } \\
\text { СЯД, } \\
\text { мкг/дм }\end{array}$ & $\begin{array}{c}\text { МДК-СЯД, } \\
\text { мкг/дм }\end{array}$ & $\begin{array}{c}\text { ГДКг/п, } \\
\text { мг/дм } \\
\text { (що діяли } \\
\text { до 01.01. } \\
2017 \text { р.) }\end{array}$ & \begin{tabular}{|c} 
ГДКр, мг/дм \\
станом на \\
31.12. \\
1992 р. / рік \\
зміни
\end{tabular} \\
\hline 1 & 2 & 3 & 4 & 5 \\
\hline Атразин & 0,6 & 2,0 & 0,5 & 0,005 \\
\hline Бензол & 10 & 50 & 0,5 & 0,5 \\
\hline $\begin{array}{c}\text { Кадмій і його } \\
\text { сполуки (залежно } \\
\text { від класів } \\
\text { орсткості води) }\end{array}$ & $\begin{array}{c}\leq 0,08 \\
\text { (клас 1) } \\
0,08 \\
\text { (клас 2) } \\
0,09 \\
\text { (клас 3) } \\
0,15 \\
\text { (клас 4) } \\
0,25 \\
\text { (клас 5) }\end{array}$ & $\begin{array}{c}\leq 0,45 \\
\text { (клас 1) } \\
0,45 \\
\text { (клас 2) } \\
0,6 \\
\text { (клас 3) } \\
0,9 \\
\text { (клас 4) } \\
1,5 \\
\text { (клас 5) }\end{array}$ & 0,001 & 0,005 \\
\hline $\begin{array}{c}\text { Тетрахлорметан } \\
\text { (чотирихлористий } \\
\text { вуглець) }\end{array}$ & 12 & $\begin{array}{c}\text { не } \\
\text { застосовується }\end{array}$ & 0,006 & $\begin{array}{c}\text { відсутність } \\
(0,000014)\end{array}$ \\
\hline $\begin{array}{c}\text { Циклодієнові } \\
\text { пестициди: } \\
\text { алдрин } \\
\text { діелдрин ендрин } \\
\text { із одрин }\end{array}$ & $\boldsymbol{\Sigma}=0,01$ & $\begin{array}{c}\text { не } \\
\text { застосовується }\end{array}$ & 0,005 & $\begin{array}{c}\text { відсутність } \\
(0,00001)\end{array}$ \\
\hline дДТ & 0,025 & $\begin{array}{c}\text { не } \\
\text { застосовується } \\
\end{array}$ & 0,1 & $\begin{array}{c}\text { відсутність } \\
(0,00001)\end{array}$ \\
\hline 1,2-Дихлоретан & 10 & $\begin{array}{c}\text { не } \\
\text { застосовується }\end{array}$ & 0,02 & 0,1 \\
\hline $\begin{array}{c}\text { Дихлорметан (хло- } \\
\text { ристий метилен) }\end{array}$ & 20 & $\begin{array}{c}\text { не } \\
\text { застосовується }\end{array}$ & 7,5 & 9,4 / 1995 p. \\
\hline Діурон & 0,2 & 1,8 & 1,0 & 0,0015 \\
\hline Гексахлорбензол & 0,01 & 0,05 & 0,05 & - \\
\hline Гексахлорбутадієн & 0,1 & 0,6 & 0,01 & - \\
\hline $\begin{array}{c}\text { Гексахлор- } \\
\text { циклогексан (ліндан) }\end{array}$ & 0,02 & 0,04 & 0,004 & $\begin{array}{c}\text { відсутність } \\
(0,00001) / \\
1995 \text { р. }\end{array}$ \\
\hline $\begin{array}{c}\text { Свинець та його } \\
\text { сполуки }\end{array}$ & $7,2^{(6)}$ & \begin{tabular}{|c|} 
не \\
застосовується
\end{tabular} & 003 & 0,1 \\
\hline Ртуть та її сполуки & 0,05 & 0,07 & 0,0005 & $\begin{array}{c}\text { відсутність } \\
(0,00001)\end{array}$ \\
\hline
\end{tabular}


Таблиця 1 (закінчення)

\begin{tabular}{|c|c|c|c|c|}
\hline $\mathbf{1}$ & 2 & 3 & 4 & 5 \\
\hline Нафталін & 2,4 & $\begin{array}{c}\text { не } \\
\text { застосовується }\end{array}$ & 0,01 & $\begin{array}{l}0,004 / \\
1995 \mathrm{p} .\end{array}$ \\
\hline $\begin{array}{c}\text { Нікель та його } \\
\text { сполуки }\end{array}$ & 20 & $\begin{array}{c}\text { не } \\
\text { застосовується }\end{array}$ & 0,1 & 0,01 \\
\hline Пентахлорфенол & 0,4 & 1 & 0,01 & - \\
\hline Симазин & 1 & 4 & відсутність & 0,0024 \\
\hline Тетрахлоретилен & 10 & $\begin{array}{c}\text { не } \\
\text { застосовується } \\
\end{array}$ & 0,02 & 0,16 \\
\hline Трихлоретилен & 10 & $\begin{array}{c}\text { не } \\
\text { застосовується }\end{array}$ & 0,06 & 0,01 \\
\hline $\begin{array}{c}\text { Сполуки трибутило- } \\
\text { лова (трибутилолова } \\
\text { катіон) } \\
\end{array}$ & 0,0002 & 0,0015 & 0,02 & $\begin{array}{c}\text { відсутність } \\
(0,00001) / \\
1995 \mathrm{p} . \\
\end{array}$ \\
\hline Трихлорбензоли & 0,4 & $\begin{array}{c}\text { не } \\
\text { застосовується }\end{array}$ & 0,03 & 0,001 \\
\hline $\begin{array}{l}\text { Трихлорметан } \\
\text { (хлороформ) }\end{array}$ & 2,5 & $\begin{array}{c}\text { не } \\
\text { застосовується } \\
\end{array}$ & 0,00 & $\begin{array}{l}0,005 / \\
1995 \mathrm{p} .\end{array}$ \\
\hline Дикофол & $1,3 \cdot 10^{-3}$ & $\begin{array}{c}\text { не } \\
\text { застосовується }\end{array}$ & - & $\begin{array}{c}\text { відсутність } \\
(0,00001) / \\
1995 \mathrm{p} . \\
\end{array}$ \\
\hline $\begin{array}{c}\text { Діоксини і діоксино- } \\
\text { подібні сполуки }\end{array}$ & - & $\begin{array}{c}\text { не } \\
\text { застосовується } \\
\end{array}$ & 0,000035 & - \\
\hline Циперметрин & $8 \cdot 10^{-5}$ & $6 \cdot 10^{-4}$ & - & $\begin{array}{l}\text { відсутність } \\
(0,0000054) \\
\end{array}$ \\
\hline Дихлофос & $6 \cdot 10^{-4}$ & $7 \cdot 10^{-4}$ & - & $\begin{array}{c}\text { відсутність } \\
(0,00001) / \\
1995 \mathrm{p} .\end{array}$ \\
\hline
\end{tabular}

У ст. 4 ДСЯД введено поняття зони змішування (33) як головного європейського еколого-правового регулятора скидання пріоритетних ЗР для визначення ГЗВ, який забезпечує дотримання вимог екологічних директив СС. У роботі ${ }^{16}$ зазначено, що 33 не тільки стосуються пріоритетних в СС ЗР, а й фактично використовуються в Україні для регулювання скидання будь-яких ЗР із точкових джерел забруднення поверхневих та морських вод. Законодавчі визначення поняття 33, вимоги до них, а також відповідні керівні документи, існують майже в усіх екологічно успішних країнах світу. Найбільший теоретичний та методичний розвиток система 33 отримала у США ${ }^{17}$.

\footnotetext{
16 Уберман В.І., Васьковець Л.А. Еколого-правові особливості імплементації ... .

17 Compilation of EPA Mixing Zone Documents. URL: https://www.epa.gov/sites/production/ files/2018-10/documents/compilation-epa-mixingzone-documents.pdf (дата звернення 09.02.2020).
} 
33 як інженерне поняття гідравліки водних об'єктів та відповідні методи розрахункового визначення характеристик 33 широко застосовуються методичними засобами для встановлення гранично допустимих скидів (ГДС) речовин у діяльності з охорони вод колишнього СРСР та пострадянських держав ${ }^{18}$, зокрема, 3 метою дотримання вимог ст. 38 ВКУ. Але нині в екологічному та водному законодавстві України 33 як правовий регулятор скидання ЗР de јите не використовується.

У ст. 4 ДСЯД для пріоритетних ЗР передбачено змогу створювати 33 у водних об'єктах поряд із пунктами скидів ЗР. При цьому в межах такої 33 концентрація однієї чи кількох ЗР може перевищувати відповідний СЯД за умови, що вона відповідає цьому СЯД на решті водоймищ поверхневих вод, тобто поза 33. Там же встановлено законодавчі вимоги до поширення та адміністрування 33. Еколого-правові особливості 33 та їх порівняння 3 нормами водного законодавства України розглядалися в роботі ${ }^{19}$. Використання 33 як природного регулятора скидання пріоритетних ЗР для визначення ГЗВ забезпечує дотримання, зокрема, вимог ВРД, ДСЯД та ДПВ.

Фізично 33 є ділянкою масиву вод, всередині якої відбуваються природні процеси, пов'язані з поширенням ЗР від джерел їх надходження (скидання). 3 правової точки зору поняття 33 дає змогу враховувати гідравлічні та гідрохімічні особливості водоймищ, зокрема, ефекти змішування, розбавлення та самоочищення зворотної води. За дією на біоту 33 дає змогу розмежувати гострі та хронічні впливи. Головні європейські вимоги до 33 встановлено у ст. 4 ДСЯД. Нині спеціальне водокористування здійснюеться в Украӥні в умовах практичної відсутності власної інженерно-екологічної бази НДМ, фінансових можливостей розвитку системи НДМ, відповідного методичного грунту. Ці обставини імплементації вимог водного законодавства ЄС підсилюють необхідність включення у ВКУ поняття СЯД як критеріальної ланки РСЗР та використання цього поняття у відповідних підзаконних актах.

Модельне зображення сфери законодавчого РСЗР в інституційній структурі водного законодавства ЄС і України наведено на рисунку 1, де використано такі позначення: ІУВРБП - інтегроване

\footnotetext{
18 Сближение с экологическим законодательством Европейского Союза ... . С. 68-81.

19 Уберман В.І., Васьковець Л.А. Поетапне наближення українського еколого-правового інституту якості вод та її регулювання до законодавства Європейського Союзу. Legislation of EU countries: history, shortcomings and prospects for the development : Collective monograph. Frankfurt (Oder) : Izdevniecība "Baltija Publishing", 2019. C. 334-354.
} 
управління водними ресурсами за басейновим принципом, ЄС (de facto) і Україна; КПТДД - комбінований підхід до точкових та дифузних джерел, СC; ICB - інститут спеціального водокористування, Україна; ІЯВР - інститут якості вод та їі регулювання, СC і Україна; НДМ - найкращі доступні технології та методи, СС; ГЗВ/ГДС - нормативне регулювання точкових джерел, СС і Україна; 33 - зони змішування, еколого-правовий інструмент ЄС і України (de facto). У зображеній структурі інструменти щодо СЯД належать першій частині ІЯВР, яка стосується якості вод.

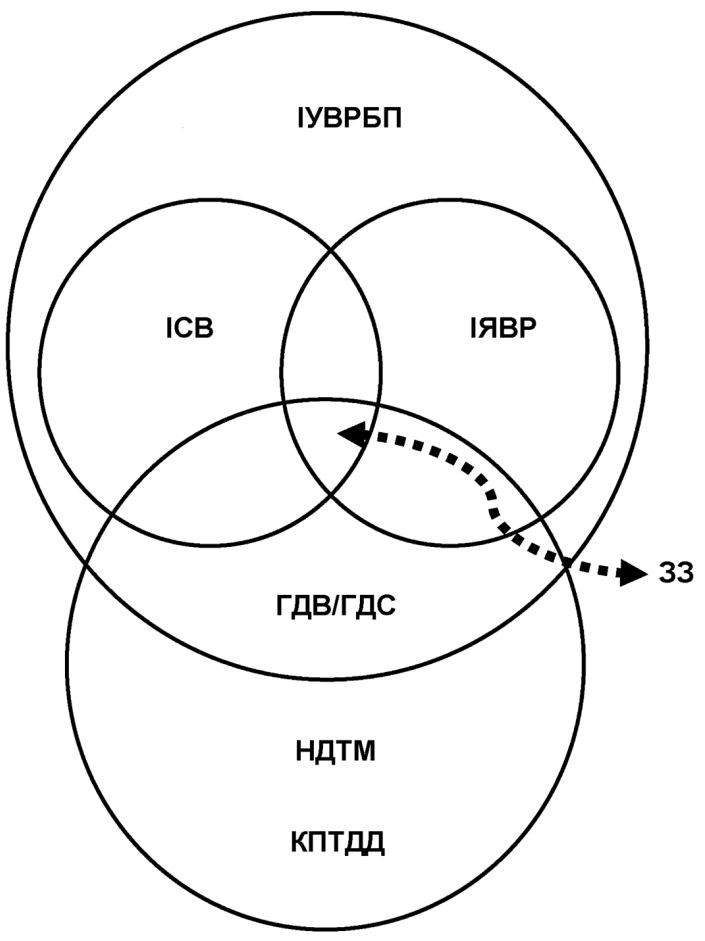

Рис. 1. Еколого-інституційна структура сфер законодавчого регулювання скидання 3Р водного законодавства ЄС і України (позначення в тексті) 


\section{2. Нормативне регулювання скидання 3Р, порівняльні особливості європейських та українських 33}

Подальші етапи апроксимації мають забезпечувати нормативне регулювання скидання ЗР. За ст.ст. 38, 41 ВКУ та за відповідними підзаконними актами українські інструменти законодавчого РСЗР нормативи гранично допустимого скидання (ГДС) розробляються та встановлюються для набагато ширшого номінаційного переліку 3Р, ніж той, що визначено у Додатку Х до ВРД стосовно пріоритетних речовин. У ст. 41 ВКУ міститься заборона скидання будь-яких речовин без встановлених нормативів екологічної безпеки водокористування та нормативів ГДС. Нині у практичній діяльності з охорони вод, всупереч вимогам ст.ст. 37, 38 ВКУ, нормативи ГДС визначаються за принципом «емісія $\longleftarrow$ іммісія» (ПЕІ $)^{20}$, а 33 виникає de facto внаслідок використання так званої «асиміляційної спроможності» (AC) водного об'єкта як ділянка обмеженого розміру біля скиду ЗР. Такі особливості українського РСЗР зумовлюють принципову відмінність його засобів регулювання від європейських. Однією з причин є невідповідність українського водного законодавства визначеним у ст. 16 ВРД стратегіям, спрямованим проти забруднення води, якими передбачено поділ ЗР за ризиком їхнього негативного впливу та, зокрема, виділення пріоритетних ЗР для боротьби із забрудненням. Але у ВКУ та в актах $3^{21}$ усі найважжливіші правові інструменти європейськой охорони вод від забруднення відсутні. Аналіз Порядку $3^{22}$, виконаний у роботі ${ }^{23}$, свідчить про грубі еколого-правові помилки в тексті цього документа, зокрема, стосовно: найменувань ЗР, об'єктів та мети нормування, поширення понять щодо масивів поверхневих вод на зворотні води, поділу ЗР на обов'язкові (в усіх випадках скидання) та додаткові, а також про невідповідність деяких важливих положень цього нормативно-правового акта вимогам ВКУ та про незадовільний рівень нормотворчої техніки. Перелік ігнорує головний принцип та регулювальний інструмент впливу на якість вод: списковий механізм поділу ЗР залежно від ризику їх негативного впливу, про що зазначено вище. Натомість

${ }_{20}$ Peter-Christoph Storm. Environmental Laws: Introduction. URL: https://www.iuscomp.org/ gla/literature/envirmt.htm (дата звернення 09.02.2020).

21 Про затвердження Порядку розроблення нормативів гранично допустимого скидання .

22 Там само.

23 Розроблення наукових пропозицій щодо визначення та встановлення зон змішування скидів забруднюючих речовин в масиви поверхневих вод України у відповідності до водного законодавства ЄС : звіт про НДР за темою № 27/1.2 (пром.), Харків. УКРНДІЕП ; кер. В.I. Уберман. № ДР 0119U102781. Харків, 2019. 243 с. 
у Переліку визначено як обов'язкові для нормування скидання 9 найбільш поширених у складі зворотної води і найменш небезпечних ЗР (або їх груп). Але для 3Р, які можуть становити реальну загрозу екологічній безпеці, обрано не деталізовану $і$ довільну процедуру нормування, реалізацію якої покладено на розпорошене коло невизначених та некерованих суб'єктів - розробників нормативів ГДС. Ці суб'єкти пов'язані з водокористувачами - замовниками розробок ГДС договірними стосунками і можуть вважатися фінансово залежними та зацікавленими особами. Крім того, додаткові для нормування ЗР визначаються не за абсолютними концентраціями у воді, а за екологічно сумнівним принципом відносного збільшення (прирощення) їх концентрації у зворотній воді. Відсутність у Переліку списків ЗР та дій із ними свідчить про невідповідність його сучасної редакції вимогам імплементації ВРД, де, як і в усьому водному законодавстві $\mathrm{CC}$, списковий принцип регулювання надходження ЗР у воду відіграє головну роль. Насправді ж, сучасні Порядок та Перелік спрямовують всю діяльність щодо системи РСЗР у бік, протилежний ефективному регулюванню.

Другий після ВКУ за значенням для діяльності з охорони якості вод акт ${ }^{24}$ (Правила) має істотне відхилення цільової спрямованості регулювального впливу від вимог ст. 38 ВКУ та орієнтований не на зменшення маси ЗР у скидах, а на господарське використання ПЕІ та АС. Визначена у п. 18 Правил мета встановлення нормативів ГДС суперечить вимозі ст. 38 ВКУ. Правила, які створювалися внаслідок реакції на суспільне визнання проблеми забруднення води, існують як окремий нормативно-правовий акт із послідовними змінами з 1961 р., варто вважати рудиментом соціалістичної охорони вод, а його норми щодо ЕПІЯВР за сучасними вимогами мали би кодифікуватися у складі ВКУ. Отже, комплекс чинних вимог до нормативного РСЗР, встановлений підзаконними актами, вимагає принципових змін: спочатку для його узгодження з ВКУ, а потім - у напрямі імплементації ВРД.

На подальших етапах апроксимації варто враховувати порівняльні особливості європейських та українських 33. Головними джерелами норм європейського та українського підінститутів РСЗР є 5 директив СC і 5 законів України та підзаконних актів, в яких визначено, відповідно, 105 та 97 релевантних структурних елементів. Особливості

\footnotetext{
24 Правила охорони поверхневих вод від забруднення зворотними водами (затв. постановою Кабінету Міністрів України від 25 березня 1999 р. № 465). URL: https://zakon.rada.gov.ua/ laws/show/465-99-п (дата звернення 09.02.2020).
} 
європейських та українських 33, які наведено в джерелах норм, порівнювалися, а їх відмінність оцінювалася за шкалою категорій, наведеною в табл. 2. Для порівняльної категорійної оцінки використовувалися законодавчі ознаки 33, наведені в табл. 3. У табл. 4 наведено зміст ознак 33 за джерелами екологічного законодавства СС 3 інтерпретацією за технічним фоновим документом ЄС з ідентифікації 33 $\left(\right.$ ТДІ 33) ${ }^{25}$. Відповідні ознаки із джерел водного законодавства України, які оцінено категоріями значної відмінності, наведено у табл. 5. У цих таблицях запис $\{C o C\}$ означає множину ЗР, щодо яких має здійснюватися регулювання.

Таблиця 2

Шкала оцінювального (за категоріями) ступеня відмінності вимог до 33 за законодавством СС та законодавством України

\begin{tabular}{|c|c|}
\hline $\begin{array}{c}\text { Категорії } \\
\text { відмінності }\end{array}$ & Оціночне визначення категорії відмінності \\
\hline 1 & принципова відмінність \\
\hline 2 & істотна відмінність \\
\hline 3 & середня відмінність \\
\hline 4 & незначна відмінність \\
\hline 5 & відсутність відмінності \\
\hline
\end{tabular}

Таблиця 3

Ознаки для порівняння європейських та українських еколого-правових вимог до 33 та їх особливостей

\begin{tabular}{|c|l|c|}
\hline $\begin{array}{c}\text { № } \\
\text { ознаки }\end{array}$ & $\begin{array}{c}\text { Головні порівняльні ознаки 33 (символ «:» } \\
\text { позначає ознаки, які мають додатковий поділ) }\end{array}$ & $\begin{array}{c}\text { Категорія } \\
\text { відмінності } \\
\text { за табл. 2 }\end{array}$ \\
\hline $\mathbf{1}$ & \multicolumn{1}{|c|}{$\mathbf{2}$} & $\mathbf{3}$ \\
\hline 1 & Наявність поняття 33 у законодавчих актах & 1 \\
\hline 2 & Обов'язковість створення (встановлення) 33 & 3 \\
\hline 3 & Мета створення (встановлення) 33 & 2 \\
\hline 4 & Сфера використання 33 & 3 \\
\hline 5 & $\begin{array}{l}\text { Місце (документ), де показується (міститься, узгод- } \\
\text { жується) інформація щодо 33 }\end{array}$ & 1 \\
\hline 6 & Обмеження для використання 33 & 1 \\
\hline 7 & Масиви вод, на яких створюється (встановлюється) 33 & 3 \\
\hline
\end{tabular}

25 Technical Background Document on Identification of Mixing Zones. URL: https://www.immissietoets.nl/documents/Technical\%20Background $\% 20$ Document $\% 20$ on $\% 20$ the\%20Identification\%20of\%20Mix.pdf (дата звернення 09.02.2020). 
Таблиця 3 (закінчення)

\begin{tabular}{|c|l|c|}
\hline $\mathbf{1}$ & \multicolumn{1}{|c|}{$\mathbf{2}$} & $\mathbf{3}$ \\
\hline 8 & $\begin{array}{l}\text { Цілі на рівні масиву вод, для досягнення яких ство- } \\
\text { рюється (встановлюється) 33: }\end{array}$ & 1 \\
\hline 9 & Скиди ЗР, для яких створюється (встановлюється) 33 & 1 \\
\hline 10 & $\begin{array}{l}\text { Сторони, що зацікавлені у створенні } \\
\text { (встановленні) 33: }\end{array}$ & 4 \\
\hline 11 & ЗР, яких стосується (щодо яких встановлюється) 33 & 4 \\
\hline 12 & $\begin{array}{l}\text { Обмеження для проектування та розміщення 33 у } \\
\text { масиві вод }\end{array}$ & 1 \\
\hline 13 & Адміністрування 33: & 3 \\
\hline 14 & $\begin{array}{l}\text { Джерело короткого опису методу, за яким визначено } \\
\text { ЗЗ, та його зміст. }\end{array}$ & 3 \\
\hline 15 & Характеристики 33: & 2 \\
\hline
\end{tabular}

Таблиця 4

Зміст ознак 33 в екологічному законодавстві СС

\begin{tabular}{|c|c|}
\hline $\begin{array}{c}\text { № } \\
\text { ознаки } \\
\text { за табл. } 2 \\
\text { за }\end{array}$ & Зміст ознаки за ДСЯД та інтерпретацісю ТДІ \\
\hline 1 & 2 \\
\hline 1 & Термін 33 наводиться в тексті, але юридично не визначається. \\
\hline 2 & $\begin{array}{l}\text { Відсутність обов'язковості створення 33, передбачається лише } \\
\text { можливість створення (встановлення) } 33 . \\
\end{array}$ \\
\hline 3 & $\begin{array}{l}\text { Зменшення концентрації ЗР, що скидається з точкового джерела, } \\
\text { до рівня СЯД у поверхневій воді на ділянці, прилеглій до точки } \\
\text { скиду. }\end{array}$ \\
\hline 4 & $\begin{array}{l}\text { Регулювання скидання певних ЗР із точкових джерел, яке дозво- } \\
\text { ляється умовою дотримання СЯД на межі поширення встанов- } \\
\text { леної } 33 .\end{array}$ \\
\hline 5 & $\begin{array}{l}\text { Плани водогосподарської діяльності в басейнах річок, що розро- } \\
\text { блені відповідно до статті } 13 \text { Директиви 2000/60/СС. Документи } \\
\text { узгодження з прилеглою державою (у випадку транскордонного } \\
\text { масиву). }\end{array}$ \\
\hline 6 & Не встановлено. \\
\hline 7 & Масиви поверхневих вод. \\
\hline 8 & $\begin{array}{l}\text { Досягнення за певною ЗР: - доброго хімічного стану масиву вод; } \\
\text { - доброго екологічного стану масиву вод. } \\
\end{array}$ \\
\hline 9 & $\begin{array}{l}\text { Скиди з усіх установок. Визначаються в регламентах установок } \\
\text { (ліцензіях, дозволах, зокрема, у попередніх). }\end{array}$ \\
\hline 10 & $\begin{array}{l}\text { Для певної 33: - водокористувачі (власники установок/скидів); } \\
\text { - компетентні органи. }\end{array}$ \\
\hline
\end{tabular}


Таблиця 4 (закінчення)

\begin{tabular}{|c|c|}
\hline 1 & 2 \\
\hline 11 & $\begin{array}{l}\text { За Частиною А Додатка I ДСЯД: пріоритетні речовини та деякі } \\
\text { інші забруднювачі. }\end{array}$ \\
\hline 12 & $\begin{array}{l}33 \text { не створюються на охоронних та чутливих ділянках (обме- } \\
\text { ження зазначаються в характеристиках певної 33). }\end{array}$ \\
\hline 13 & $\begin{array}{l}\text { Суб’єкт адміністрування - компетентний орган. Види адміні- } \\
\text { стрування: створення (встановлення), регулювання характерис- } \\
\text { тик, ліквідація } 33 .\end{array}$ \\
\hline 14 & За ТДІ. \\
\hline 15 & 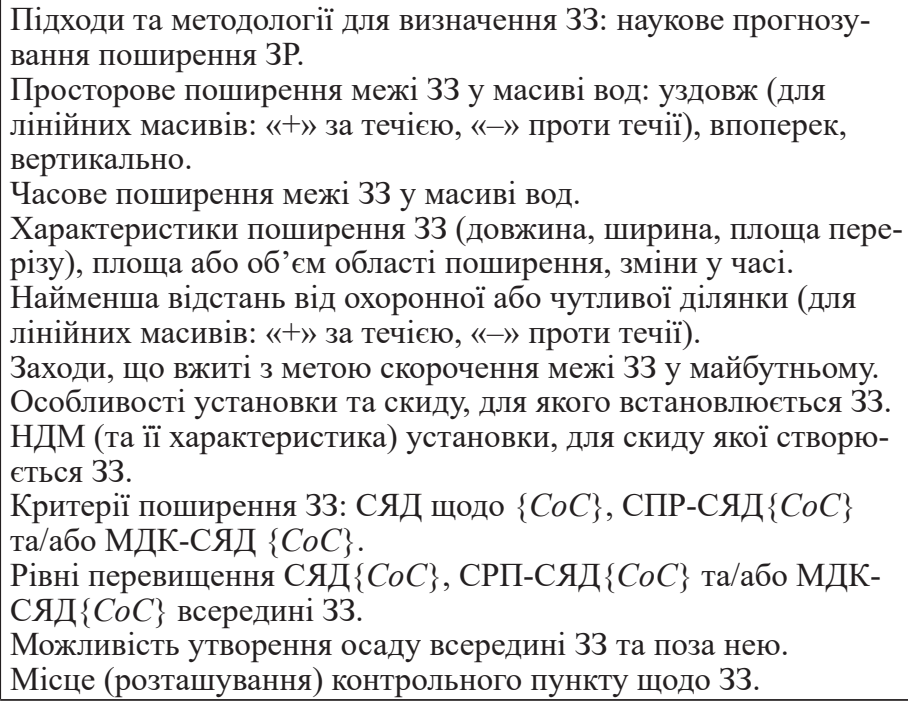 \\
\hline
\end{tabular}

Таблиця 5

\section{Зміст ознак 33, які характеризуються категоріями}

значної відмінності (1, 2, 3 за табл. 2),

за водним законодавством України

\begin{tabular}{|c|l|}
\hline $\begin{array}{l}\text { № ознаки } \\
\text { за табл. }\end{array}$ & \multicolumn{1}{|c|}{ Зміст ознаки за ВКУ та підзаконними актами } \\
\hline $\mathbf{1}$ & \multicolumn{1}{|c|}{$\mathbf{2}$} \\
\hline 1 & $\begin{array}{l}\text { Термін 33 у тексті не наводиться, але поняття змістовно вико- } \\
\text { ристовується в інструктивно-методичному документі. }\end{array}$ \\
\hline 2 & $\begin{array}{l}\text { Обов'язковість фактичного існування 33. Існують деякі } \\
\text { винятки. }\end{array}$ \\
\hline 3 & $\begin{array}{l}\text { Визначення нормативів ГДС ЗР для поетапного досягнення еко- } \\
\text { логічного нормативу якості води водних об'єктів. }\end{array}$ \\
\hline
\end{tabular}


Таблиця 5 (продовження)

\begin{tabular}{|c|c|}
\hline 1 & 2 \\
\hline 4 & $\begin{array}{l}\text { Використання і охорона вод та відтворення водних ресурсів у } \\
\text { частині скидання ЗР із зворотною водою з точкових джерел в } \\
\text { обсягах, які допускаються вимогами поетапного досягнення } \\
\text { екологічного нормативу якості води та нормативами ГдК. }\end{array}$ \\
\hline 5 & $\begin{array}{l}\text { Для діючих водокористувачів - у документації, яка додається до } \\
\text { дозволів на спеціальне водокористування. } \\
\text { Для підприємств, що проектуються, - у складі передпроектної } \\
\text { та проектно-кошторисної документації (проект, робочий про- } \\
\text { ект) на нове будівництво, розширення, реконструкцію і технічне } \\
\text { переоснащення. }\end{array}$ \\
\hline 6 & У випадках, визначених у ч. 2 ст. 70 , ст.ст. $72-74$ ВКУ. \\
\hline 7 & $\begin{array}{l}\text { Масиви поверхневих вод, за виключенням ділянок: для задово- } \\
\text { лення питних, господарсько-побутових та інших потреб насе- } \\
\text { лення; в межах територій населених пунктів. }\end{array}$ \\
\hline 8 & $\begin{array}{l}\text { Поетапне досягнення екологічного нормативу якості води } \\
\text { стосовно: } \\
\text { 1) ГДКг/п (для певної ЗР); 2) ГДКр (для певної ЗР); 3) допусти- } \\
\text { мих концентрацій радіоактивних речовин у водних об'єктах, } \\
\text { вода яких використовується для задоволення питних, господар- } \\
\text { сько-побутових та інших потреб населення (для певної ЗР). }\end{array}$ \\
\hline 9 & $\begin{array}{l}\text { Скиди: діючих водокористувачів; підприємств, що проекту- } \\
\text { ються, будуються, розширюються, реконструюються, технічно } \\
\text { переоснащуються та капітально ремонтуються. }\end{array}$ \\
\hline 12 & $\begin{array}{l}\text { Зони часткової або повної заборони водокористування за ст. } 54 \\
\text { ВКУ. } \\
\text { Води, що використовуються для задоволення питних і господар- } \\
\text { сько-побутових потреб населення. Водні об'єкти, зараховані до } \\
\text { категорії лікувальних за ст. } 63 \text { ВКУ. Води, які використовуютья } \\
\text { в оздоровчих, рекреаційних та спортивних цілях за ст. } 64 \text { ВКУ. } \\
\text { Місця водокористування та їх охоронні зони. Ділянки водних } \\
\text { об'єктів у межах населених пунктів. Місце скидання стічних } \\
\text { вод має знаходитися нижче межі населеного пункту за течією } \\
\text { водотоку на відстані, яка виключає вплив згінно-нагінних явищ. } \\
\text { Охоронні зони ділянок водних об'єктів, які використовуютья } \\
\text { для задоволення питних і господарсько-побутових потреб, на } \\
\text { відстані одного кілометра вище від найближчого за течією } \\
\text { пункту водокористування, а на водоймах - акваторії в радіусі } \\
\text { одного кілометра від пункту водокористування. Води, які вико- } \\
\text { ристовуються для потреб рибного господарства. }\end{array}$ \\
\hline 13 & $\begin{array}{l}\text { Суб’єкти адміністрування: органи, що уповноважені видавати } \\
\text { дозвіл на спеціальне водокористування. Види адміністрування: } \\
\text { створення (встановлення), регулювання характеристик, призупи- } \\
\text { нення існування, припинення існування, заборона існування } 33 .\end{array}$ \\
\hline 14 & За Інструкцією про розроблення ГДС. \\
\hline
\end{tabular}


Таблиця 5 (закінчення)

\begin{tabular}{|c|c|}
\hline 1 & 2 \\
\hline 15 & 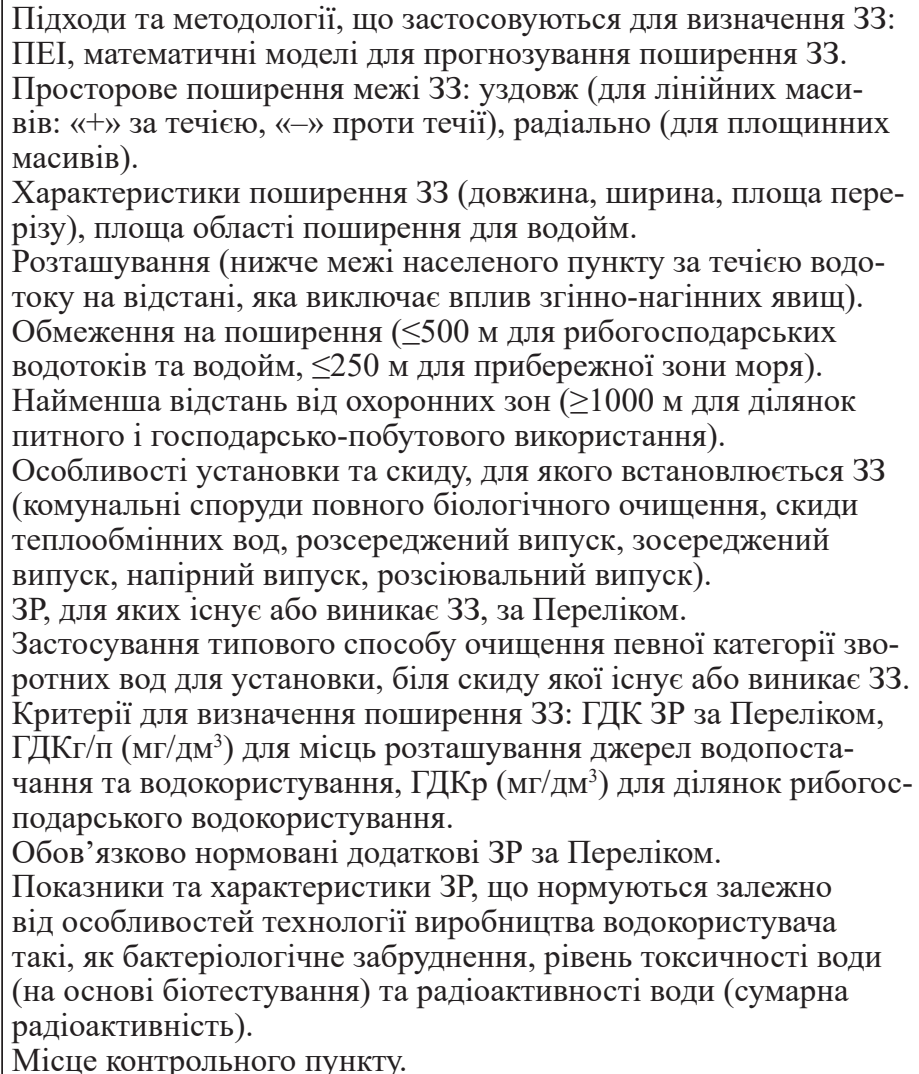 \\
\hline
\end{tabular}

Загалом за оцінювальним порівнянням ознак у табл. 3 та табл. 4 ступені відмінності європейського та українського законодавств розподіляються за кількістю ознак у відповідних категоріях таким чином: принципова відмінність - 7; істотна відмінність - 1; середня відмінність - 5; незначна відмінність - 2; відсутність відмінності - 0 (загалом 15 оцінювальних ознак). Отже, можна стверджувати про наявність значних відмінностей між європейськими та українськими еколого-правовими вимогами до 33 при скиданні ЗР та необхідність їх усунення для належної апроксимації. 


\section{ВИСНОВКИ}

Забезпечення доброї якості води в українських природних джерелах вимагає запровадження європейської системи охорони вод та ефективного наближення українського водного законодавства до вимог екологічного законодавства ЄС. Відповідні вимоги обох законодавств зосереджено в ЕПІЯВР та підінституті РСЗР. Першочергової імплементації в українське водне законодавство вимагають головні структурні елементи європейського РСЗР, до яких належать: списковий поділ ЗР за ризиком їхнього негативного впливу на довкілля; методи регулювання емісії ЗР, що базуються на НДМ; законодавче регулювання скидання ЗР нормативами ГПВ/ГДС із дотриманням ЕСЯ поза 33 зворотної води. Для сучасного стану української охорони вод найважливішим варто вважати головний складник РСЗР: законодавчу інструменталізацію 33. Імплементації відповідних еколого-правових інструментів перешкоджають такі проблеми: істотна відмінність юридичного змісту базового поняття «забруднення» в українському та європейському законодавствах; відсутність законодавчого поділу ЗР за їх небезпекою та необхідністю боротьби з небезпечними речовинами; невідповідність українських нормативних характеристик стану якості вод (ГДК) європейським СЯД; відсутність НДМ або подібних йому інструментів у водному законодавстві України; відсутність законодавчого визначення 33 та вимог до них; помилки в підзаконних актах, які стосуються скидання ЗР. Така глибока розбіжність означає, що парадигма української охорони вод вимагає зміни з господарської на екологічну. Визначено, що в українському водному законодавстві фактично є та використовується аналог 33 як інженерно-екологічний об'єкт, який виникає в процесі нормативного регулювання скидання ЗР за допомогою нормативів ГДС. За оцінювально-категорійним порівнянням головних ознак 33 в екологічному законодавстві ЄС та вимог до скидання ЗР у водному законодавстві України між ними виявлено значні відмінності та зазначено необхідність їх усунення. Отримані результати можуть застосовуватися задля розроблення законопроектних та нормопроектних пропозицій, головною метою яких є забезпечення переходу до європейського регулювання скидання небезпечних забруднюючих речовин із дотриманням екологічних стандартів якості вод. Альтернативою зазначеної глибокої екологізації ВКУ вартр вважати розроблення та прийняття спеціального Закону України «Про охорону вод». 


\section{АНОТАЦІЯ}

У статті досліджено європейський еколого-правовий інститут регулювання скидання забруднюючих речовин із точкових джерел у поверхневі води та проблеми його імплементації в українське водне законодавство. Визначено, що українські базові критерії якості води гранично допустимі концентрації речовин принципово відрізняються від європейських стандартів якості довкілля за своїм цільовим призначенням, формою та змістом. Також визначено, що у сучасних українських умовах головним європейським інструментом дотримання стандартів якості довкілля щодо пріоритетних для ЄС забруднюючих речовин $є$ зони змішування зворотної води, за характеристиками яких водокористувачам мають встановлюватися нормативні обмеження на скидання забруднюючих речовин: граничні значення виділення або допустимі скиди. Нині зони змішування як правовий регулятор скидання забруднюючих речовин в екологічному та водному законодавстві України de jure не застосовуються. Вони використовуються в Україні de facto як інженерне поняття гідравліки водних об'єктів у методичних документах для встановлення граничних допустимих скидів речовин із метою дотримання нормативів гранично допустимих концентрацій речовин у воді. Для першочергової імплементації європейського регулювання скидання забруднюючих речовин в українське водне законодавство треба: здійснити в останньому законодавче поділення забруднюючих речовин за їх значенням для охорони вод; визначити та включити у Водний кодекс України та підзаконні акти європейське поняття стандарту якості довкілля; запровадити списковий підхід до регулювання скидання забруднюючих речовин з огляду на ризик їх шкідливого впливу; кодифікувати вимоги різних актів щодо охорони вод від забруднення у складі Водного кодексу України. Шляхом порівняння законодавчих інструментів регулювання скидання забруднюючих речовин виявлено наявність значних відмінностей між європейськими та українськими еколого-правовими вимогами до зон змішування та необхідність їх усунення у процесі імплементації.

\section{ЛІТЕРАТУРА}

1. Рекомендації для українських органів державного управління щодо наближення до права ЄC. Київ, 2018. 104 p. URL: https://eu-ua.org/sites/ default/files/inline/files/legal_approximation_guidelines_ukr_new.pdf (дата звернення 09.02.2020).

2. Уберман В.І., Васьковець Л.А. Еколого-правові особливості імплементації Україною законодавства ЄС про регулювання скидання 
забруднюючих речовин. International scientific and practical conference "New challenges of legal science in Ukraine and EU countries" Miskolc, Hungary, April 19-20, 2019. Miskolc: Izdevnieciba "Baltija Publishing”, 2019. P. 437-440.

3. Данилюк Л.Р. Басейновий принцип управління водними ресурсами: поняття, зміст і стан впровадження в Україні. Науковий вісник Ужгородського наи. ун-ту. Сер. Право. 2018, Вип. 51. Т. 1. С. 151-154. URL: http://www.visnyk-juris.uzhnu.uz.ua/file/No.51/part_1/34.pdf (дата звернення 09.02.2020).

4. Соколова А.К. Правові аспекти державного управління в галузі охорони вод і відтворення водних ресурсів. Проблеми законності. 2015. Вип. 128. С. 154-164. URL: http://nbuv.gov.ua/UJRN/Pz_2015_128_22 (дата звернення 09.02.2020).

5. Локтєва-Маклашова Н.В. Правові аспекти впровадження інтегрованих підходів в управління водними ресурсами за басейновим принципом. Науковий вісник Херсонського держ. ун-ту. Сер. Юридичні науки. 2017. Вип. 1(1). С. 142-144. URL: http://nbuv.gov.ua/UJRN/Nvkhdu_ jur_2017_1(1)_37 (дата звернення 09.02.2020).

6. Водний кодекс України. ВВР. 1995. № 24. Ст. 189. URL: https://zakon.rada.gov.ua/laws/show/213/95-вр (дата звернення 09.02.2020).

7. Директива 2000/60/ЄС Європейського Парламенту і Ради «Про встановлення рамок діяльності Співтовариства в галузі водної політики» від 23 жовтня 2000 p. URL: https://zakon.rada.gov.ua/laws/show/994_962 (дата звернення 09.02.2020).

8. Концепція реалізації державної політики у сфері промислового забруднення (проект розпорядження Кабінету Міністрів України. URL: https://menr.gov.ua/projects/140/ (дата звернення 09.02.2020).

9. Кобецька Н.Р. Інтегрований екологічний дозвіл: вимоги законодавства Європейського Союзу, практика реалізації в Польщі, перспективи для України. Науковий вісник Ужгородського наи. ун-ту. Сер. Право. 2018 51(1). C. 155-163. URL: http://www.visnyk-juris.uzhnu.uz.ua/ file/No.51/part_1/35.pdf (дата звернення 09.02.2020).

10. Кобецька Н.Р. Система документів дозвільного характеру у сфері використання природних ресурсів. Актуальні проблеми вдосконалення чинного законодавства Украӥни. 2013. Вип. 33. С. 187-199. URL: http://nbuv.gov.ua/UJRN/apvchzu_2013_33_23 (дата звернення 09.02.2020).

11. Директива 2008/105/СС Європейського Парламенту та Ради від 16 грудня 2008 р. про стандарти якості довкілля в галузі водної політики. URL: http://old.minjust.gov.ua/45875 (дата звернення 09.02.2020).

12. Водний кодекс України.

13. Перелік забруднюючих речовин для визначення хімічного стану масивів поверхневих і підземних вод та екологічного потенціалу штучного 
або істотно зміненого масиву поверхневих вод (затв. наказом Міністерства екології та природних ресурсів України 06.02.2017 р. № 45, зареєстр. в Міністерстві юстиції України 20 лютого 2017 р. за № 235/30103). URL: https://zakon.rada.gov.ua/laws/show/z0235-17?lang=ru (дата звернення 09.02.2020).

14. Про затвердження Порядку розроблення нормативів гранично допустимого скидання забруднюючих речовин у водні об'єкти та перелік забруднюючих речовин, скидання яких у водні об'єкти нормується (затв. постановою Кабінету Міністрів України від 11 вересня 1996 р. № 1100 (в редакції Постанови КМ № 1091 (1091-2017-п) від 13.12.2017 p. URL: http://zakon.rada.gov.ua/laws/show/1100-96-п (дата звернення 13.01.2020).

15. Сближение с экологическим законодательством Европейского Союза в странах Восточной Европы, Кавказского региона и Средней Азии: Путеводитель. Люксембург. Бюро офиц. публ. Европейских Сообществ. 2003. 124 c. URL: https://ec.europa.eu/environment/archives/enlarg/pdf/ convergence_guide_ru.pdf (дата звернення 09.02.2020).

16. Уберман В.І., Васьковець Л.А. Еколого-правові особливості імплементації Україною законодавства СС про регулювання скидання забруднюючих речовин. International scientific and practical conference "New challenges of legal science in Ukraine and EU countries" Miskolc, Hungary, April 19-20, 2019. Miskolc: Izdevnieciba "Baltija Publishing”, 2019. P. $437-440$

17. Compilation of EPA Mixing Zone Documents. URL: https:/www.epa.gov/sites/production/files/2018-10/documents/compilationepa-mixingzone-documents.pdf (дата звернення 09.02.2020).

18. Сближение с экологическим законодательством Европейского Союза в странах Восточной Европы, Кавказского региона и Средней Азии: Путеводитель. Люксембург. Бюро офиц. публ. Европейских Сообществ. 2003. 124 c. URL: https:/ec.europa.eu/environment/archives/enlarg/pdf/ convergence_guide_ru.pdf (дата звернення 09.02.2020).

19. Уберман B.I., Васьковець Л.А. Поетапне наближення українського еколого-правового інституту якості вод та їі регулювання до законодавства Свропейського Союзу. Legislation of EU countries: history, shortcomings and prospects for the development. Collective monograph. Frankfurt (Oder). Izdevniecība "Baltija Publishing". 2019. P. 334-354.

20. Peter-Christoph Storm. Environmental Laws: Introduction. URL: https://www.iuscomp.org/gla/literature/envirmt.htm (дата звернення 09.02.2020).

21. Про затвердження Порядку розроблення нормативів гранично допустимого скидання забруднюючих речовин у водні об'єкти 1076 
та перелік забруднюючих речовин, скидання яких у водні об'єкти нормується (затв. постановою Кабінету Міністрів України від 11 вересня 1996 р. № 1100 (в редакції Постанови КМ № 1091 (1091-2017-п ) від 13.12.2017 p. URL: http://zakon.rada.gov.ua/laws/show/1100-96-п (дата звернення 13.01.2020).

\section{2. Там само.}

23. Розроблення наукових пропозицій щодо визначення та встановлення зон змішування скидів забруднюючих речовин в масиви поверхневих вод України у відповідності до водного законодавства СС : звіт про НДР за темою № 27/1.2 (проміж.), Харків : УКРНДІЕП; кер. В.І. Уберман. № ДР 0119U102781. Харків, 2019. 243 с.

24. Правила охорони поверхневих вод від забруднення зворотними водами (затв. постановою Кабінету Міністрів України від 25 березня 1999 р. № 465). URL: https://zakon.rada.gov.ua/laws/show/465-99-п (дата звернення 09.02.2020).

25. Technical Background Document on Identification of Mixing Zones. 09.02.2011. URL: https://www.immissietoets.nl/ documents/Technical\%20 Background $\% 20$ Document $\% 20$ on $\% 20$ the $\% 20$ Identification $\% 20$ of $\% 20$ Mix. $\operatorname{pdf}$ (дата звернення 09.02.2019).

\section{Information about authors:}

Uberman V. I., Ph.D., Leading Scientific Researcher of the Water Quality Regulation Laboratory State Scientific and Research Institution "Ukrainian Scientific and Research Institute of Environmental Problems" 6, Bakulina str., Kharkiv, Ukraine

Vaskovets L. A., Ph.D.,

Professor of the Occupational Safety and Environment Protection Department National Technical University "Kharkiv Polytechnic Institute" 2, Kyrpychova str., Kharkiv, Ukraine DOI https://doi.org/10.30525/978-9934-588-43-3/2.25 